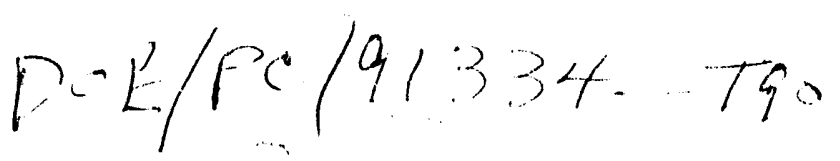

$\mathrm{DOE} / \mathrm{PC} / 91334--\mathrm{T} 90$

TECHNICAL REPORT

DE93 000956

March 1, 1992 through May 31, 1992

\title{
INTEGRATED METHODS FOR PRODUCTION OF CLEAN CHAR AND ITS COMBUSTION PROPERTIES DE-FG22-91PC 91334
}

Principal Invest.: Joseph A. DeBarr, Illinois State Geological Survey (ISGS)

Co-Investigators : Massoud Rostam-Abadi, ISGS; Brian K. Gullett, U. S. EPA; Steven A. Benson and Donald L. Toman, University of North Dakota Energy and Environmental Research Center (UNDEERC)

Project Monitor : Frank Honea: CRSC

\section{ABSTRACT}

The objective of this two-year program is to produce chars with $\mathrm{SO}_{2}$ emissions at least $50 \%$ lower than those of the parent coals, and which at minimum meet the year 1995 emission standard of 2.5 lbs $\mathrm{SO}_{2} / \mathrm{MMBtu}$. This will be accomplished using an integrated process which combines physical coal cleaning, mild gasification and char desulfurization. This project is a cooperative effort between the ISGS, UNDEERC and the U.S. EPA and is cost-shared with the U.S. EPA and the U.S. DOE through UNDEERC.

Mild gasification and char desulfurization studies are conducted in both a batch fluidized-bed reactor and in a continuous rotary kiln reactor using six coals selected from the Illinois Basin Coal (IBC) Sample Program. Burning characteristics and ash deposition behaviors of desulfurized chars are determined at the U.S. EPA in a $14 \mathrm{~kW}$ pilot-scale combustor and at UNDEERC in a drop tube furnace (DTF). Complete analyses of the fuels are obtained to aid char desulfurization studies and help explain combustion and $\mathrm{SO}_{2}$ emission characteristics of the chars.

During this reporting period, preliminary low temperature oxidation (LTO) studies were conducted to desulfurize chars derived from mild gasification. Under non-optimized conditions, $\mathrm{SO}_{2}$ emissions (1bs $\mathrm{SO}_{2} / \mathrm{MMBtu}$ ) of the six coals were reduced over $60 \%$. Physical coal cleaning, mild gasification and char desulfurization reduced the $\mathrm{SO}_{2}$ emissions of two of the coals nearly $70 \%$. Chars prepared from four of the six coals tested had $\mathrm{SO}_{2}$ emissions of less than 2.5 lbs $\mathrm{SO}_{2} / \mathrm{MMBtu}$. The average yield of low sulfur char obtained after pyrolysis and LTO was nearly $64 \%$ by weight of the original coal.

Thermogravimetric (TG) experiments showed that LTO chars are easier to burn than mild gasification chars, due to an increase in surface areas of desulfurized chars during oxygen treatment. Surface areas measured by nitrogen adsorption were 126 to $234 \mathrm{~m}^{2} / \mathrm{g}$ for LTO chars and $<5 \mathrm{~m}^{2} / \mathrm{g}$ for mild gasification chars.

\section{MASIER} DISTRIBUTION OF THIS DOCUMENT IS UNRIMTTE:

This project is funded by the U. S. Department of Energy (METC) and by the Illinois Department of Energy and Natural Resources as part of their costshared program. 


\section{EXECUTIVE SUMMARY}

\section{Background}

To meet the years 1995 and 2000 emissions guidelines of 2.5 and 1.2 1bs $\mathrm{SO}_{2} /$ MMBtu, utilities burning high-sulfur Illinois coals must consider either installing a scrubber unit (wet or dry), or switching to a low sulfur fuel, or a combination of these alternatives. The use of a low cost, low sulfur char with acceptable burning characteristics could be an attractive alternative to coal-switching or coal-blending both of which decrease utilization of Illinois coal. In addition, the low sulfur char could be used by utilities which can not add scrubbers due to cost or space limitations. The low sulfur char can be used directly as a compliance fuel, co-fired with methane, or blended with Illinois coal to reduce emission levels of the coal.

\section{Goals and Objectives}

The objective of this two-year program is to produce chars with $\mathrm{SO}_{2}$ emissions at least $50 \%$ lower than those of the parent coals, and which at minimum meet the year 1995 emission standard of 2.5 lbs $\mathrm{SO}_{2} / \mathrm{MMBtu}$. This will be accomplished using an integrated process which combines physical coal cleaning, mild gasification and char desulfurization. This project is a cooperative effort between the ISGS, UNDEERC and the U.S. EPA and is cost-shared with the U.S. EPA and the U.S. DOE through UNDEERC.

The project has six tasks. In the first task, screening studies are conducted to select candidate coals for clean char production. Chars from six coals are produced under mild gasification conditions. In the second task, chars are subjected to low temperature oxidation to remove additional sulfur. Thermodynamic studies will be conducted to help design experiments. Optimized conditions for maximum sulfur removal are determined for coals selected from screening studies. In the third task, fifty pounds of low sulfur chars are prepared using a continuous rotary tube kiln (RTK) under optimal conditions determined from batch studies. Coal-char blends having 25 and 35 percent volatile matter (VM) are prepared from the chars. In the fourth task, combustion behaviors of the desulfurized chars are determined in a $14 \mathrm{~kW}$ pilot-scale combustor located at U.S. EPA. In the fifth task, ash deposition behaviors are obtained for selected fuels in a drop tube furnace (DTF) at UNDEERC. In the sixth task, physical (porosity, pore surface ared and particle size distribution) and chemical (proximate and ultimate analyses, ash chemistry and ash fusion chemistry) properties of the fuels are obtained to aid desulfurization studies and to help explain combustion and ash slagging and fouling properties.

\section{Progress to date}

Six coals from the IBC sample program (IBC-101, 102, 104, 105, 106 and 109) were used for preliminary char production Each was was subcted to a step wise grinding and sieving techniqu $100 \times 200$ mesh 
to a step wise grinding and sieving technique to prepare $100 \times 200$ mesh fuels. Results indicate that all coals except IBC-105 exhibit identical grinding behaviors. The initial mean particle diameter of IBC-105 was much smaller than the other coals, and much less grinding was required to obtain a $100 \times 200$ mesh sample.

Due to their high ash content, IBC-104 and IBC-105 coals were physically cleaned prior to char production. Mild gasification chars were prepared for desulfurization studies in a 1 -inch $i$.d. fluidized-bed reactor system by heating the coals under $50 \% \mathrm{~N}_{2} / 50 \%$ steam to $525^{\circ} \mathrm{C}$. Analyses of the fuels indicate that during pyrolysis, $\mathrm{SO}_{2}$ emissions ( $1 \mathrm{~b} \mathrm{SO}_{2} / \mathrm{MMBtu}$ ) of the coals are reduced $19-41 \%$. Combustion reactivities (burning profiles) of the coals and chars indicate that chars have slightly higher burnout temperatures than their parent coals.

During the reporting period, preliminary low temperature oxidation (LTO) studies were conducted to desulfurize chars derived by mild gasification. Under non-optimized conditions, $\mathrm{SO}_{2}$ emissions (lbs $\mathrm{SO}_{2} / \mathrm{MMBtu}$ ) of the six coals were reduced over $60 \%$. The $\mathrm{SO}_{2}$ emissions of IBC-102 coal were reduced $64 \%$ from 4.60 to 1.64 ibs $\mathrm{SO}_{2} / \mathrm{MMBt}$. Physical coal cleaning followed by mild gasification and char desulfurization reduced the $\mathrm{SO}_{2}$ emissions of two of the coals nearly $70 \%$. However, for the IBC-105 sample, by-passing the physical coal cleaning step still resulted in a char with sulfur emissions $66 \%$ lower than that of the parent coal. This is because LTO focuses primarily on removing pyritic sulfur, which is the same type of sulfur removed by physical coal cleaning. Chars prepared from four of the six coals had $\mathrm{SO}_{2}$ emissions less than $2.51 \mathrm{bs} \mathrm{SO}_{2} / \mathrm{MMBtu}$. Overall, $\mathrm{SO}_{2}$ emissions of the LTO chars ranged from 0.92 to 3.52 lbs $\mathrm{SO}_{2} / \mathrm{MMBtu}$. The average yield of low sulfur char obtained after pyrolysis and LTO was nearly $64 \%$ by weight of the original coal.

Thermogravimetric (TG) experiments showed that LTO chars are easier to burn than mild gasification chars, which is attributed to an increase in surface areas of desulfurized chars during oxygen treatment. Surface areas measured by nitrogen adsorption were 126 to $234 \mathrm{~m}^{2} / \mathrm{g}$ for LTO chars and $<5 \mathrm{~m}^{2} / \mathrm{g}$ for mild gasification chars.

\section{DISCLAIMER}

\footnotetext{
This report was prepared as an account of work sponsored by an agency of the United States Government. Neither the United States Government nor any agency thereof, nor any of their employees, makes any warranty, express or implied, or assumes any legal liability or responsibility for the accuracy, completeness, or usefulness of any information, apparatus, product, or process disclosed, or represents that its use would not infringe privately owned rights. Reference herein to any specific commercial product, process, or service by trade name, trademark, manufacturer, or otherwise does not necessarily constitute or imply its endorsement, recommendation, or favoring by the United States Government or any agency thereof. The views and opinions of authors expressed herein do not necessarily state or reflect those of the United States Government or any agency thereof.
} 


\section{OBJECTIVES}

The objectives of this research are to produce a clean char and determine combustion and emission characteristics of the char and coal-char blends.

The specific goals of the contract are:

A. Determine desulfurization potential of various Illinois coals.

B. Modify an existing rotary tube kiln (RTK) for continuous char production and low temperature oxidation tests.

c. Prepare pound quantities of clean char in the RTK.

D. Prepare coal-char blends with $25 \%$ and $35 \%$ VM.

E. Obtain physical and chemical properties of the fuels.

F. Determine combustion properties and $\mathrm{SO}_{2}$ emissions of coal, char, and coal-char blends under conditions representative of coal-fired boilers.

G. Determine ash deposition behaviors of selected fuels under conditions representative of coal-fired boilers.

\section{INTRODUCTION AND BACKGROUND}

In the past several years, the CRSC and U.S. DOE have funded research programs which have focused on producing premium liquids by mild gasification of coal. The principle product (about 60-70 percent by weight) of mild gasification processes is a partially devolatilized coal (herein referred to as char) that must be effectively utilized to help the overall economics of the process. The loss of VM indicates loss of hydrocarbon materials from the coal that are desirable for ignition, carbon burn-out and flame stability. In addition, the char produced from processing high-sulfur Illinois coals still contains a high residual sulfur content which exceeds the 1995 and 2000 emissions limits of 2.5 and $1.2 \mathrm{Ibs} \mathrm{SO}_{2} / \mathrm{MMBtu}$.

To meet 1995 emissions guidelines, utilities burning high-sulfur Illinois coal are considering coal-switching or blending Illinois coal with lowsulfur western coal. Either scenario would ultimately decrease utilization of Illinois coal. Another alternative is using post-combustion scrubbers to remove $\mathrm{SO}_{2}$ from stack gases. However, scrubbers are too costly for older plants and are not suitable for utilities with limited space for installing a unit. In addition, not all utilities can build and operate scrubbers by 1995 even if they desire to do so. Therefore, alternatives must be developed to be used until 2000 . 
Investigators at the ISGS have previously studied gas phase desulfurization by hydrogen treatment (Stephenson et al., 1987). Although a low sulfur char can be achieved by hydrogen treatment, the process would produce a char that would be difficult to burn because of reduced VM and reactivity due to the relatively high processing temperature. Recent research conducted by the investigators at the ISGS and others suggest that a high-sulfur Illinois coal (many emitting $>5$ lbs $\mathrm{SO}_{2} / \mathrm{MMBtu}$ ) may produce a clean char with 18 percent $V M$ and emissions of $<2.5$ lbs $\mathrm{SO}_{2} / \mathrm{MMBtu}$ by selecting appropriate conditions during mild gasification followed by a low temperature oxidation step. However, neither optimized conditions for sulfur removal, nor combustion characteristics of the clean char have been researched extensively. Combustion characteristic data obtained at the ISGS under several CRSC-funded programs indicate that the char derived under mild gasification conditions, when mixed with coal to make a 25 percent VM blend, can be burned with an acceptable combustion efficiency in pulverized coal (PC) boilers (DeBarr et al., 1991).

A low sulfur char can be burned at a compliance level in a boiler designed to burn low volatile fuels, or in conventional PC boilers with or without an auxiliary fuel such as methane or by blending with high-sulfur Illinois coal or low-sulfur Western coal. A low sulfur char could also be an ideal feed stock for production of oxidized char or carbon molecular sieves. Methods for producing these two valuable products from Illinois coal are currently being studied at the ISGS (Kruse et al., 1991; Lizzio et al., 1991).

\section{EXPERIMENTAL}

\section{Task 1. Acquisition and Preparation of Fuels}

The objective of this task is to prepare chars from various Illinois coals to be used in low temperature oxidation studies (Task 2). The results from these screening studies should enhance the understanding of the effect of coal characteristics (including total sulfur and types of sulfur) on the extent of desulfurization.

Details of char production using six coals selected from the Illinois Basin Coal (IBC) sample program were presented in the previous reporting period. One additional char was prepared from physically cleaned IBC-105 coal during the current period. The $100 \times 200$ mesh parent coal was washed with hot distilled water to remove any soluble calcium ions, then filtered and dried. A slurry was formed by mixing the sample with a solution of sodium polytungstate and distilled water with specific gravity of 1.4 . The slurry was centrifuged to separate the minerai matter and clean coal. The float fraction was decanted, filtered, washed with hot water and airdried. The sink fraction was discarded.

A fluidized-bed reactor (FBR) system, shown in figure 1 , was used for production of char. The reactor consisted of a 24-inch length of 1-inch $i . d$. stainless steel. The distributor plate was porous hastelloy- $X$ stainless steel and was located 9.75 inches from the bottom of the 
reactor. The reactor was heated externally by a 2 -inch, 1900 Watt, model 3210 Applied Test Systems split tube furnace. An LFE model 2011 temperature controller was used to control the temperature of the reactor. A Barber Coleman model 121L limit controller monitored a thermocouple in the furnace and was used to protect the furnace from accidental overheating. A thermocouple mounted in the center of the reactor monitored the bed temperature.

Char production was done with 30 grams of $100 \times 200$ mesh cleaned IBC-105 coal, which was fluidized by $50 \% \mathrm{~N}_{2} / 50 \%$ steam and heated to $525^{\circ} \mathrm{C}$ using a staged heating method to eliminate agglomeration. The sample was held at $525^{\circ} \mathrm{C}$ for 30 minutes, then cooled and stored under $\mathrm{N}_{2}$.

\section{Task 2. Low temperature oxidation studies}

The purpose of this task is to remove additional sulfur from the chars prepared in task 1. Low temperature oxidation (LTO) studies were done in the 1-inch FBR described above, which was connected to Rosemount Analytical model 280 non-dispersive infrared $\mathrm{CO}$ and $\mathrm{CO}_{2}$ analyzers, and a Teledyne Analytical Instruments model $691 \mathrm{SO}_{2}$ analyzer (see figure 1). In a typical run, 1-5 grams of char were fluidized by $50 \% \mathrm{~N}_{2} / 50 \%$ steam and heated to a temperature between 415 and $485^{\circ} \mathrm{C}$. The fluidizing gas was changed to $5 \% \mathrm{O}_{2} / 45 \% \mathrm{~N}_{2} / 50 \%$ steam, and the $\mathrm{CO}, \mathrm{CO}_{2}$ and $\mathrm{SO}_{2}$ concentrations were monitored by computer as a function of time.

Task 3. Char production in the RTK

No work was performed for this task during the reporting period.

\section{Task 4. Combustion studies}

Burning profiles of fuel samples were obtained with an Omnitherm thermogravimetric analyzer (TGA) coupled with an Omnitherm QC25 Programmer/Controller. Details of the system have been given elsewhere (RostamAbadi et al., 1989). The TGA system was interfaced with an IBM PC-XT computer through a Keithley DAS series 500 data acquisition system to provide automated data collection and storage. A sample mass of 2 to $4 \mathrm{mg}$ was loaded into the platinum pan of the TGA and was heated at a constant heating rate of $20^{\circ} \mathrm{C} / \mathrm{min}$ in a $10 \% \quad 0_{2}-90 \% \mathrm{~N}_{2}$ gas mixture to $700^{\circ} \mathrm{C}$. A gas flow rate of $200 \mathrm{cc} / \mathrm{min}$ (STP) was used. The percent weight of the unburned sample, the rate of weight loss, and the gas temperature in the vicinity of the sample pan were collected by the computer at 15 second intervals.

\section{Task 5. Ash Deposition Experiments}

No work was performed for this task during the reporting period. 


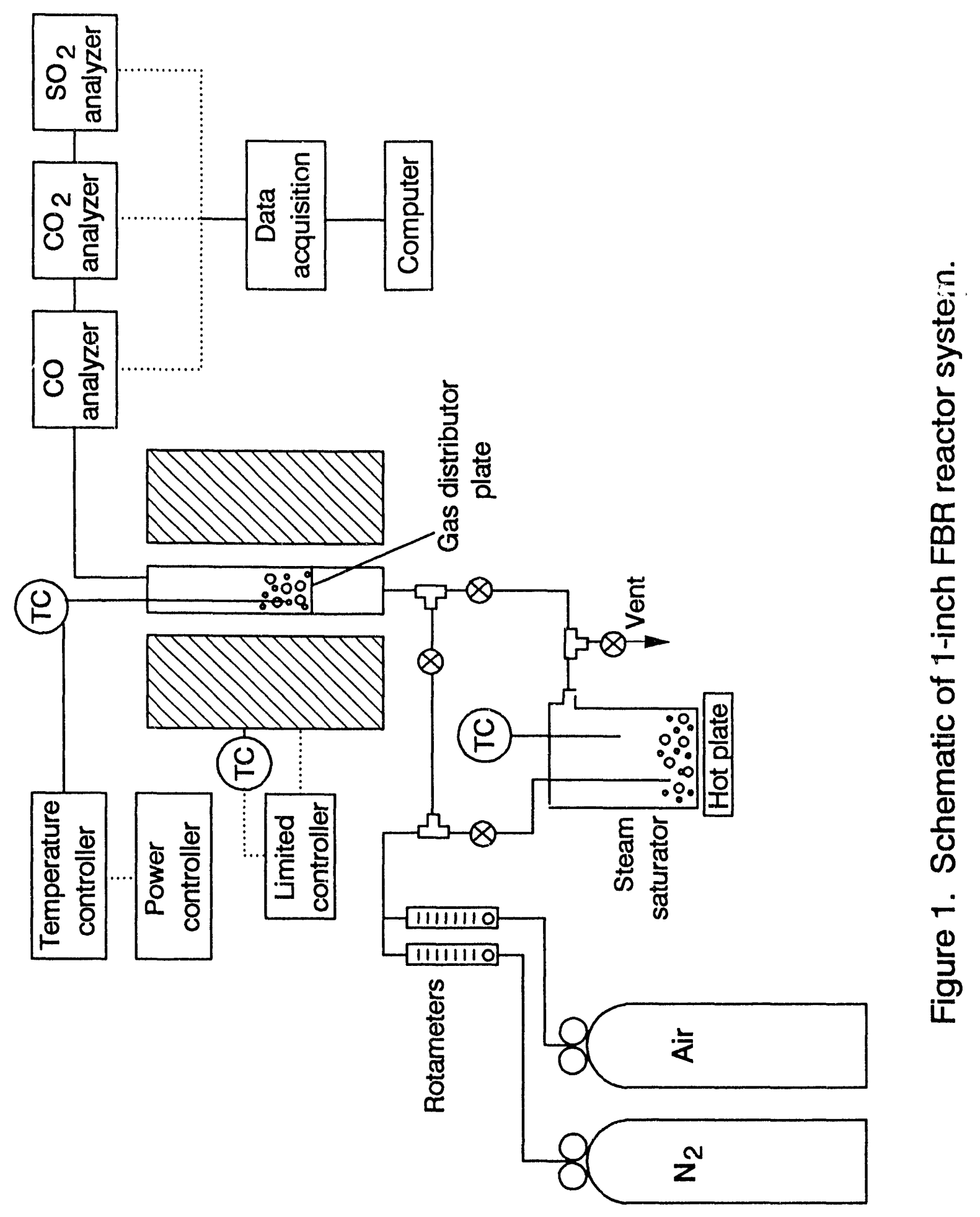


Task 6. Physical and Chemical Characterization

\section{Proximate and UItimate Analyses}

The proximate analyses of the fuels were obtained by an automatic LECO MAC 400 and the ultimate analyses were done using a LECO CHN 600 analyzer. A LECO SC32 analyzer was used to obtain total sulfur content. Forms of sulfur were determined according to method ASTM 2942. Analyses were performed at the ISGS Coal Analysis Laboratory.

\section{Specific Surface Areas}

The principal of physical adsorption of gases was used to determine specific surface areas of the solid fuels. Data obtained from nitrogen and carbon dioxide absorptions at -196 and $-77^{\circ} \mathrm{C}$, respectively, were used in conjunction with the Brunauer, Emmett, and Teller (BET) equation (Smith, 1981) to determine the BET $\left(\mathrm{N}_{2}\right)$ and BET $\left(\mathrm{CO}_{2}\right)$ specific surface areas. Experiments were conducted at the ISGS Physical Chemistry Laboratory. 


\section{RESULTS AND DISCUSSION}

\section{Task 1. Acquisition and Preparation of Fuels}

See task 6 for analyses of the fuels prepared. The samples prepared in this task are designated as char-101, char-102, char-104, char-105, char106 and char-109, with the suffix number referring to the parent coal.

\section{Task 2. Low temperature oxidation studies}

Preliminary oxidation studies were done to determine the effect of temperature and gas flow rate on the amount of sulfur removed in the form of $\mathrm{SO}_{2}$, and the amount of carbon gasified to $\mathrm{CO}$ and/or $\mathrm{CO}_{2}$. A higher yield of low sulfur char can be obtained by maximizing the $\mathrm{SO}_{2}: \mathrm{CO}_{2}$ ratio. Two temperatures which give relatively slow and rapid rates of carbon burn-off were selected from burning profiles of the chars (see task 4). Results for LTO tests for char-102 are shown in figure 2. The $\mathrm{CO}_{2}$ and $\mathrm{SO}_{2}$ concentrations are normalized to the same flow rate of carrier gas, and the $\mathrm{CO}$ concentrations are not included to facilitate clarity. In each case, the initial release of $\mathrm{SO}_{2}$ is very rapid and the $\mathrm{SO}_{2}$ concentration returns to zero after seven minutes. The amounts of $\mathrm{SO}_{2}$ and $\mathrm{CO}_{2}$ evolved increase with increasing temperature and flow rate. The maximum $\mathrm{SO}_{2}: \mathrm{CO}_{2}$ ratio for a given time is obtained with higher temperatures and flow rates. Therefore, LTO production runs were done under these conditions. During a production run, the gas concentrations were monitored, and the oxidation was stopped when the $\mathrm{SO}_{2}$ concentration returned to zero.

\section{Task 3. Char production in the RTK}

No work was performed for this task during the reporting period.

\section{Task 4. Combustion studies}

Reactivities of the fuels are obtained to ensure production of a sufficiently reactive char and aid in selection of temperatures which will minimize carbon loss during low temperature oxidation studies.

Burning profiles refer to a plot of the TGA rate of weight loss against temperature as a sample is burned in air at a constant heating rate. Typical burning profile and weight loss curves of $100 \times 200$ mesh IBC-10I coal burning in $10 \% \mathrm{O}_{2}-90 \% \mathrm{~N}_{2}$ are shown in figure 3 . The weight loss curve shows a slight gain in weight between 200 and $320^{\circ} \mathrm{C}$ due to the tendency of coal to adsorb oxygen in this temperature range. A major weight loss begins at $354^{\circ} \mathrm{C}\left(\mathrm{T}_{1}\right.$, the temperature corresponding to a rate of weight loss of $1 \% / \mathrm{min}$ ) and peaks at about $510^{\circ} \mathrm{C}\left(T_{p}\right)$. The rate of burning then decreases until sample oxidation is complete at a burnout temperature $\left(T_{B}\right)$ of about $584^{\circ} \mathrm{C}$, where the rate of weight loss is again $1 \% / \mathrm{min}$. The weight remaining at $700^{\circ} \mathrm{C}$ is the ash content of the sample, which is about $11 \%$. Under the conditions used, characteristic temperatures $\left(T_{I}, T_{p}\right.$, and $\left.T_{B}\right)$ were reproducible within $2 \%$. 


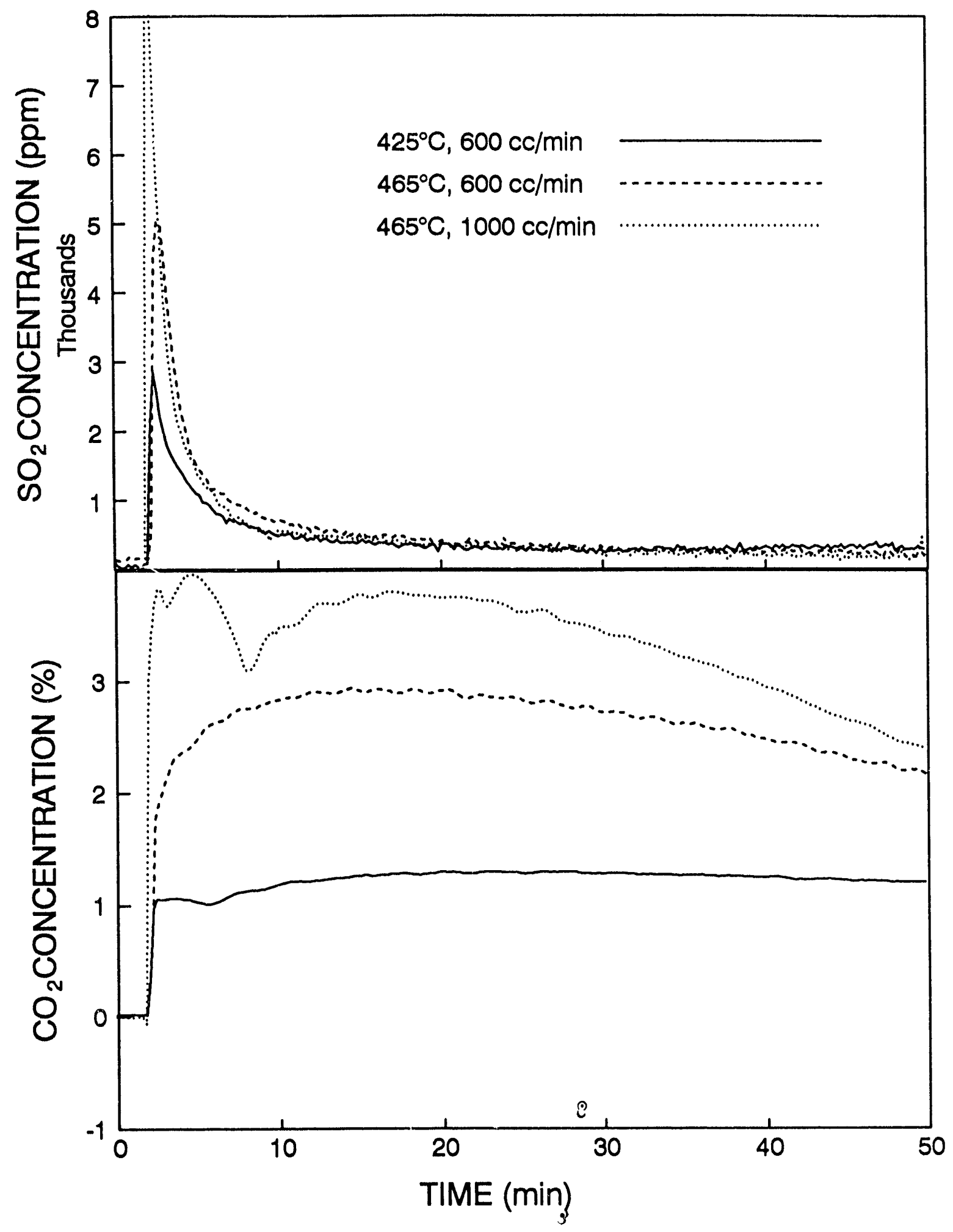

Figure 2. Characteristic curves for $\mathrm{SO}_{2}$ and $\mathrm{CO}_{2}$ evolution during LTO of char-102. 


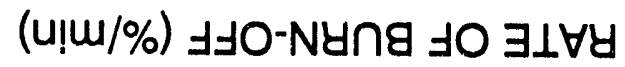

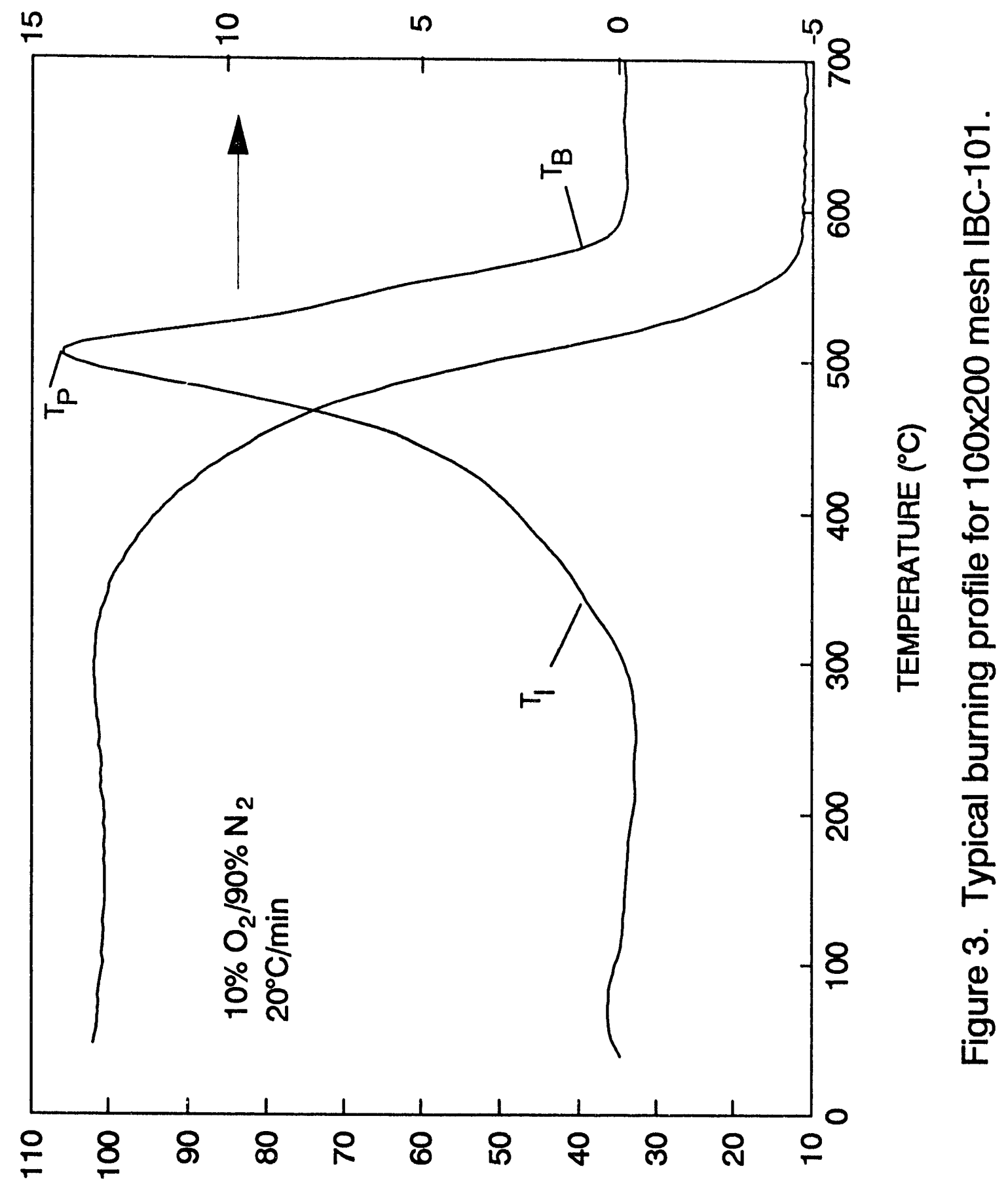

(\%) פNINI $\forall W \exists Y \perp H פ I \exists M$ 
Burning profiles are useful for determining the relative combustion characteristics of a fuel. According to published reports (Wagoner and Winegartner, 1973), fuels which give similar burning profiles exhibit similar combustion reactivities in larger furnaces. More reactive fuels exhibit lower characteristic temperatures. Characteristic temperatures of the fuels were obtained from the burning profiles and are listed in table 1. Results for the coals and chars were presented during the previous reporting period, but are shown here for comparison to the LTO chars.

Table 1. Characteristic temperatures* for coals and chars $\left({ }^{\circ} \mathrm{C}\right)$.

\begin{tabular}{llll}
\hline Sample & $T_{1}$ & $T_{p}$ & $T_{B}$ \\
\hline IBC-101 & 354 & 510 & 584 \\
IBC-102 & 351 & 516 & 590 \\
IBC-104 & 374 & 525 & 601 \\
IBC-105 & 377 & 516 & 589 \\
IBC-106 & 372 & 518 & 601 \\
IBC-109 & 386 & 529 & 602 \\
Char-101 & & & \\
Char-102 & 429 & 531 & 591 \\
Char-104 & 436 & 544 & 615 \\
Char-105 & 440 & 536 & 601 \\
Char-106 & 451 & 551 & 610 \\
Char-109 & 451 & 549 & 624 \\
& 464 & 562 & 635 \\
LTO-101 & & & \\
LTO-102 & 427 & 523 & 581 \\
LTO-104 & 437 & 543 & 614 \\
LTO-105 & 434 & 529 & 596 \\
LTO-106 & 443 & 540 & 602 \\
LTO-109 & 446 & 540 & 617 \\
\hline AII Va14 & 458 & 556 & 627 \\
\hline
\end{tabular}

*All values are average of two or more runs.

The chars all have higher characteristic temperatures than their parent coals. The greatest difference is for $T_{1}$ which represents only the onset of oxidation for chars, whiie for coals, $T_{1}$ represents a combined effect of VM evolution and subsequent char oxidation. The LTO chars exhibit lower characteristic temperatures than their precursor chars. This could be explained by the increased surface area of the LTO chars (see task 6), which would allow greater access to the carbonaceous material and an observed increase in reactivity. These results suggest that LTO chars are easier to burn than the mild gasification precursor chars. 
Task 5. Ash Deposition Experiments

No work was performed for this task during the reporting period.

Task 6. Physical and Chemical Characterization

\section{Proximate and ultimate analyses}

The LECO proximate and ultimate analyses for the six coals and a discussion of significant results were presented in the previous reporting period. The analyses are presented again in table 2 to facilitate comparison of these samples to those prepared this period. Table 2 also includes analyses for the physically cleaned IBC-105 coal prepared during this reporting period. The amount of ash in the cleaned coal is $5.3 \%$ which corresponds to a $66 \%$ decrease compared to the parent coal. Physically cleaning IBC-105 reduces the pyritic sulfur content and theoretical $\mathrm{SO}_{2}$ emissions ( $1 \mathrm{~b} \mathrm{SO} / \mathrm{MMBtu}$ ) $79 \%$ and $48 \%$. These results are similar to results obtained by cleaning IBC-104 coal.

The analyses of the six chars prepared during the previous reporting period are shown in table 3 to facilitate discussions. Analyses for the char prepared from cleaned IBC-105 coal is also shown in table 3 . This sample contains $14.8 \%$ VM which is comparable to the chars prepared from the other coals. Pyrolyzing cleaned IBC-105 coal increases the amount of ash in the sample by about $50 \%$. The average higher heating value increases less than $2 \%$, while the total sulfur content is reduced $32 \%$. This results in a $33 \%$ reduction of $\mathrm{SO}_{2}$ emissions ( $1 \mathrm{~b} \mathrm{SO}_{2} / \mathrm{MMBt} \mathrm{M}$ ) compared to the clean coal. Overall, the $\mathrm{SO}_{2}$ emissions of $\mathrm{IBC}-105$ are reduced $65 \%$ by physical coal cleaning followed by pyrolysis. These results are comparable to results obtained during the previous reporting period for pyrolyzing physically cleaned IBC-104 coal.

The proximate analyses of chars prepared by LTO are shown in table 4 . The LTO chars appear to have higher VM contents than the precursor chars (table 3), which is explained by the adsorption of oxygen during preparation, and the subsequent formation of stable C-0 surface complexes. The VM contents for LTO chars include the weight percent attributed to these C-0 complexes, as well as actual VM present, resulting in a higher value.

Using non-optimized LTO conditions, the amount of sulfur in the char is reduced between 11 and $62 \%$ (average reduction of $33 \%$ ), while the higher heating value is reduced an average of about $6 \%$. This results in theoretical $\mathrm{SO}_{2}$ emissions 8 to $57 \%$ (average of $30 \%$ ) lower than the precursor chars (table 3 ).

Overall, pyrolysis followed by LTO produces chars with $\mathrm{SO}_{2}$ emissions an average of $61 \%$ lower than those of their parent coals (table 2), with values between 0.92 and 3.52 Ibs $\mathrm{SO}_{2} / \mathrm{MMBtu}$. Of the six coals selected for desulfurization studies, four of these produced chars with ernissions of 


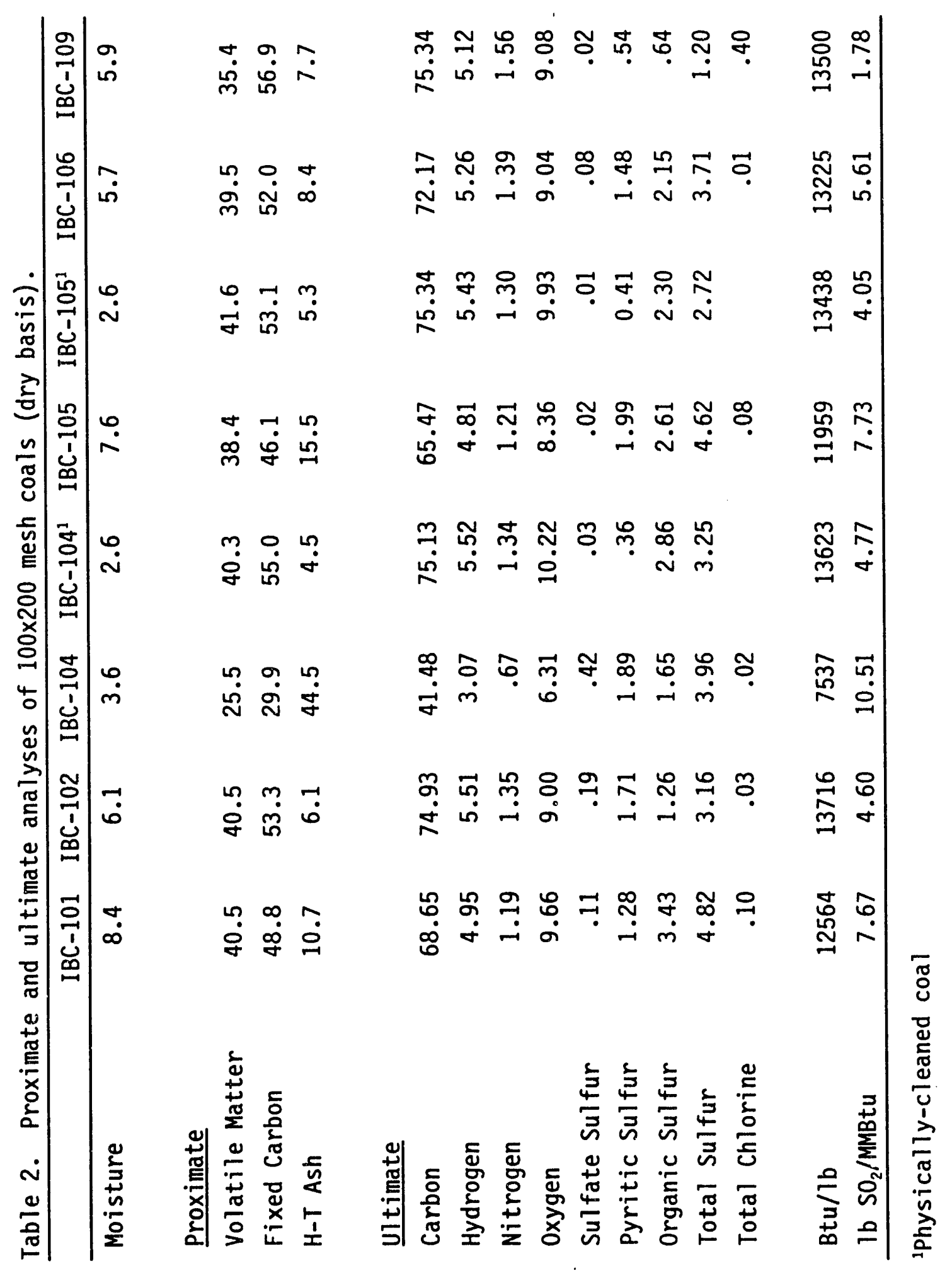




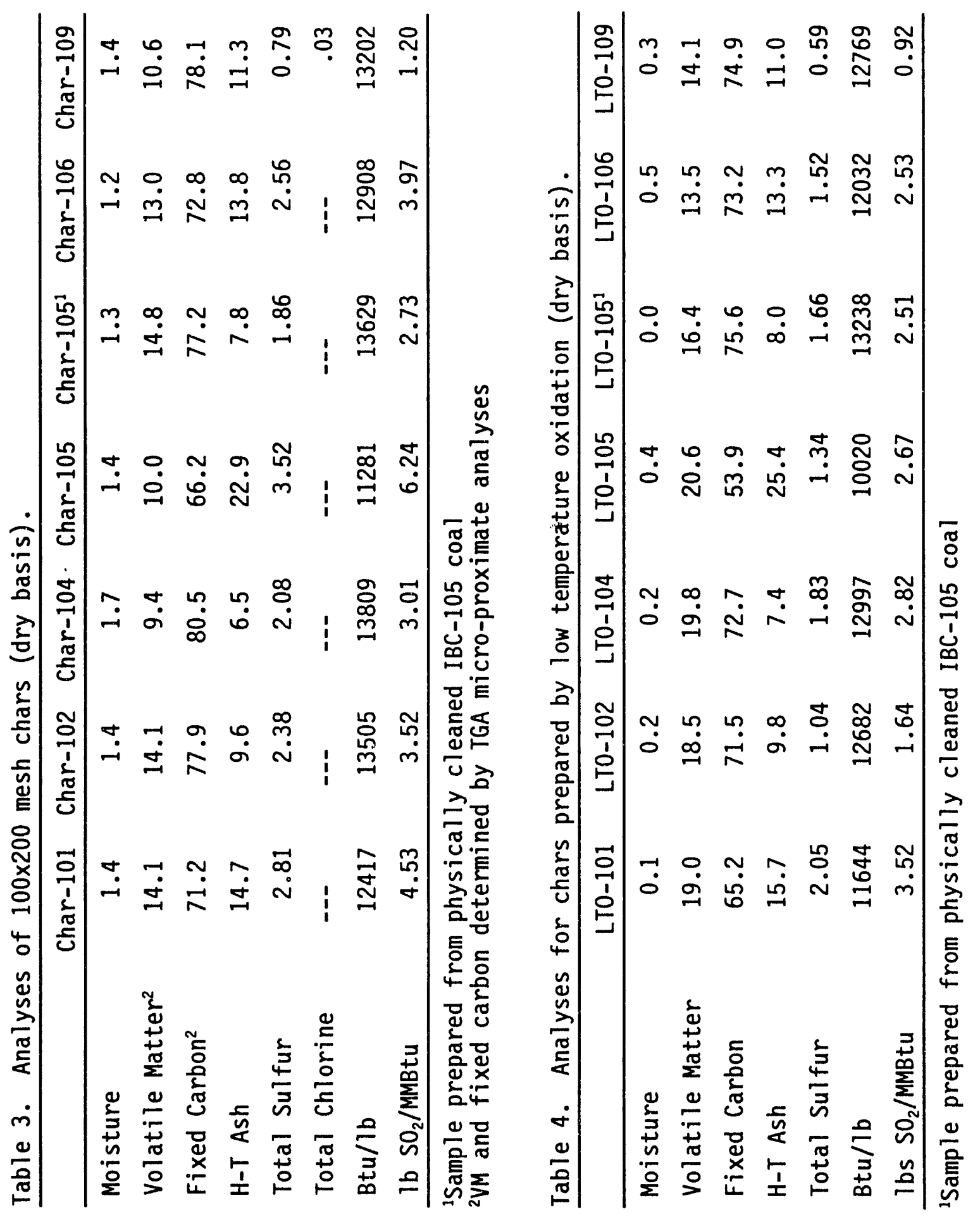


$2.5 \mathrm{lbs} \mathrm{SO}_{2} / \mathrm{MMBt}$ or lower, using non-optimized processing conditions. The $\mathrm{SO}_{2}$ emissions of IBC -102 coal is reduced from 4.60 to 1.64 lbs $\mathrm{SO}_{2} / \mathrm{MMBtu}$ by pyrolysis and LTO. Overall yields for the process were determined using an ash tracer technique, which assumes the ash in the sample is not affected by the processing steps. The average yield obtained after pyrolysis and LTO was nearly $64 \%$ by weight of the original coal.

Physical coal cleaning followed by pyrolysis and LTO reduces the $\mathrm{SO}_{2}$ emissions for IBC-104 and IBC-105 coals $73 \%$ and $68 \%$, respectively. However, eliminating the physical coal cleaning step from processing IBC105 coal still produces a char with $\mathrm{SO}_{2}$ emissions $66 \%$ lower than the parent coal (see table 4). The physically cleaned LTO char has $\mathrm{SO}_{2}$ emissions of 2.51 lbs $\mathrm{SO}_{2} / \mathrm{MMBtu}$ compared to $2.67 \mathrm{lbs} \mathrm{SO}_{2} / \mathrm{MMBtu}$ for the sample which was not cleaned. This suggests that physical coal cleaning has a minimal effect on the amount of sulfur removed from this coal by the overall process. This is because LTO focuses primarily on removing pyritic sulfur from the char, which is the same type of sulfur removed by physical coal cleaning.

\section{Surface Areas}

The $\mathrm{N}_{2}$-BET and $\mathrm{CO}_{2}$-BET surface areas of the LTO chars and their precursor chars are shown in table 5. The surface areas of the parent coals were not determined, but would be expected to have $\mathrm{N}_{2}-\mathrm{BET}$ and $\mathrm{CO}_{2}-\mathrm{BET}$ surface areas of about 50 and $200-300 \mathrm{~m}^{2} / \mathrm{g}$, respectively. The chars prepared by pyrolysis had significantly lower surface areas as measured by $\mathrm{N}_{2}-\mathrm{BET}$ than the parent coals. The removal of $V M$ should create more porosity and therefore more surface area. It appears that during devolatilization, a large fraction of the pores in the coal that were accessible to $\mathrm{N}_{2}$ at $196^{\circ} \mathrm{C}$ were partially plugged. This is in agreement with results found previously by the authors (DeBarr et al., 1991).

The $\mathrm{N}_{2}$-BET surface areas of the LTO chars range from 126 to $234 \mathrm{~m}^{2} / \mathrm{g}$ indicating that LTO opens pores which were not accessible to $\mathrm{N}_{2}$ after pyrolysis. The differences in surface areas of the LTO chars suggest that the chars were subjected to different levels of carbon burn-off, which was responsible for the development of porosity. However, the level of carbon burn-off was not monitored during LTO studies. The $\mathrm{CO}_{2}-\mathrm{BET}$ surface areas of the LTO chars is significantly higher than those of the precursor chars. This indicates that the network of smaller pores developed during devolatilization were opened during oxidation.

\section{SUMMARY AND CONCLUSIONS}

During the reporting period, preliminary low temperature oxidation (LTO) studies were conducted to desulfurize chars derived by mild gasification. Under non-optimized conditions, $\mathrm{SO}_{2}$ emissions (1bs $\mathrm{SO}_{2} / \mathrm{MMBtu}$ ) of the six coals are reduced over $60 \%$. $\mathrm{SO}_{2}$ emissions of IBC-102 coal were reduced $64 \%$ from 4.60 to 1.64 lbs $\mathrm{SO}_{2} / \mathrm{MMBtu}$. Physical coal cleaning followed by mild gasification and char desulfurization reduced the $\mathrm{SO}_{2}$ emissions of two of the coals nearly $70 \%$. However, for IBC-105 coal, eliminating the physical 
coal cleaning step still resulted in a char with sulfur emissions $66 \%$ lower than that of the parent coal. This is because LTO focuses primarily on removing pyritic sulfur, which is the same type of sulfur removed by physical coal cleaning. Four of the six coals produced chars with emissions less than 2.5 lbs $\mathrm{SO}_{2}$ /MMBtu. Overall, $\mathrm{SO}_{2}$ emissions of the LTO chars ranged from 0.92 to 3.52 lbs $\mathrm{SO}_{2} / \mathrm{MMBtu}$. The average yield of low sulfur char obtained after pyrolys is and LTO was nearly $64 \%$ by weight of the original coal.

Table 5. Surface areas of chars and LTO chars $\left(\mathrm{m}^{2} / \mathrm{g}\right)$.

\begin{tabular}{lcc}
\hline & $\mathrm{N}_{2}(\mathrm{BET})$ & $\mathrm{CO}_{2}(\mathrm{BET})$ \\
\hline Char-101 & $<5$ & 306 \\
Char-102 & $<5$ & 261 \\
Char-104 & $<5$ & 347 \\
Char-105 & $<5$ & 334 \\
Char-106 & $<5$ & 318 \\
Char-109 & $<5$ & 315 \\
& & \\
LT0-101 & 165 & 407 \\
LT0-102 & 234 & 450 \\
LTO-104 & 231 & 495 \\
LTO-105 & 126 & 406 \\
LT0-106 & 168 & 410 \\
LT0-109 & 135 & 381 \\
\hline
\end{tabular}

'Samples prepared from physically-cleaned coals.

Thermogravimetric (TG) experiments showed that LTO chars are easier to burn than mild gasification chars, which is attributed to an increase in $\mathrm{N}_{2}$-BET surface areas of desulfurized char during oxygen treatment. Surface areas were 126 to $234 \mathrm{~m}^{2} / \mathrm{g}$ for LTO chars and $<5 \mathrm{~m}^{2} / \mathrm{g}$ for mild gasification chars.

During the next reporting period, work will focus on char preparation in the RTK, and optimization of processing conditions for sulfur removal. 


\section{REFERENCES}

DeBarr, J. A., M. Rostam-Abadi, R. D. Harvey, C. Feizoulof, S. A. Benson, and D. L. Toman, 1991. "Reactivity and combustion properties of coal-char blend fuels." Final Technical Report to the Center for Research on Sulfur in Coal. September, 1991.

Hackley, K. C., R. R. Frost, C-L. Liu, S.J. Hawk and D. D. Coleman, 1990. "Study of sulfur behavior and removal during thermal desulfurization of Illinois coals". Illinois State Geol. Survey Circ. \#545.

Khan, M. R., 1989. "Prediction of sulphur distribution in products during low temperature coal pyrolysis and gasification." Fuel, 68(11), pp 14391449.

Kruse, C. W., J. M. Lytle, M. Chou, S. M. Fatemi, Y. C. Lin, M. RostamAbadi, C. Feizoul of and J. Mahoney, 1991. "Upgrading mild gasification char: Evaluation of oxidized char as catalyst." Final Technical Report to the Center for Research on Sulfur in Coal. September, 1991.

Lizzio, A. A. and M. Rostam-Abadi, 1991. "Production of carbon molecular sieves from Illinois coal". Quarterly chnical Report to the Center for Research on Sulfur in Coal for the period 9/1/91-12/1/91, Carterville, IL.

Oh, M.S., A. K. Burnham and R. W. Crawford, 1988. "Evolution of sulfur gases during coal pyrolysis." Paper prepared for submittal to American Ceramics Society Meeting, June 5-12, Toronto, Canada.

Rostam-Abadi, M., J. A. DeBarr, R. D. Harvey, S. A. Benson, D. P. McCollor, 1989. Reactivity and combustion properties of coal-derived solid fuels. Final Technical Report, CRSC, Champaign, IL.

Smith, J. M., 1981. "Chemical engineering kinetics". McGraw-Hill, New York.

Stephenson, M. D., C.-L. Liu, K. C. Hackley, D. D. Coleman, S. J. Hawk and A. D. Williams, 1987. "Desulfurization of Illinois coals by thermal, chemical and magnetic methods". Final Technical Report to the CRSC, Champaign, IL.

Stephenson, M. D., M. Rostam-Abadi, L. A. Johnson and C. W. Kruse, 1985. "A review of gas phase desulfurization of char". Y. A. Attia, ed., in Processing and Utilization of High Sulfur Coals 9, Elsevier, The Netherlands, $787 \mathrm{pp}$.

Wagoner, C. L. and E. C. Winegartner, 1973. Further development of the burning profile. Journal of Engineering for Power, April, pg. 119-123. 
1

\section{PROJECT MANAGEMENT}

March 1, 1992 through May 31, 1992

\section{INTEGRATED METHODS FOR PRODUCTION OF CLEAN CHAR AND ITS COMBUSTION PROPERTIES}

Principal Invest.: Joseph A. DeBarr, Illinois State Geological Survey (ISGS)

()-Investigators : Massoud Rostam-Abadi, ISGS; Brian K. Gullett, U. S. EPA; Steven A. denson and Donald L. Toman, University of North Dakota Energy and Environmental Research Center (UNDEERC)

Project Monitor : Frank Honea, CRSC

\section{COMMENTS}

Other Direct Costs for this period includes work performed by the University of North Dakota which will not be done until the next reporting period.

This project is funded by the U. S. Department of Energy (METC) and by the Illinois Department of Energy and Natural Resources as part of their costshared program. 


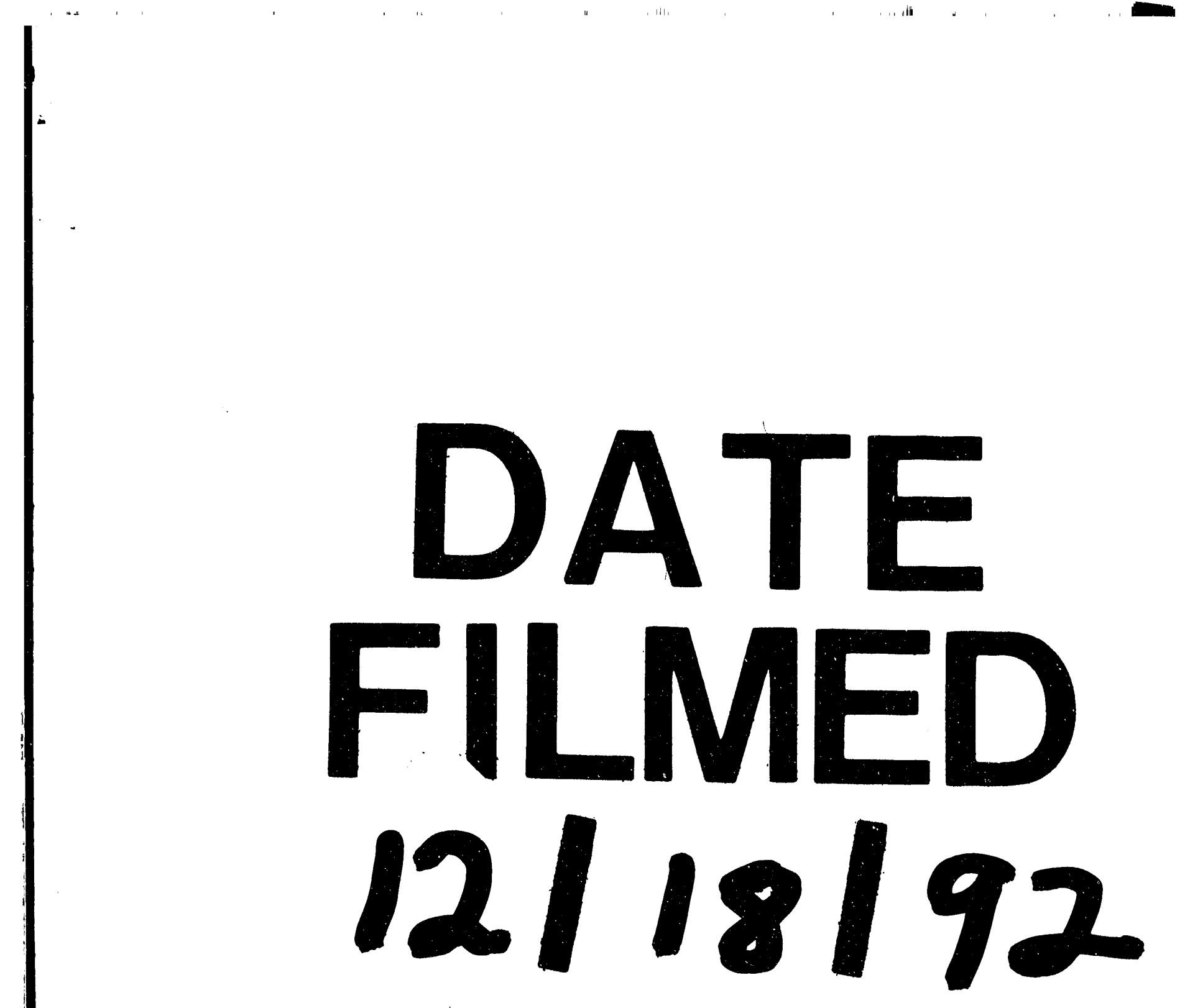


